\title{
Israelvisie: destruksie of dekonstruksie?
}

\author{
PM Venter
}

\begin{abstract}
Israel vision: Destruction or deconstruction?

Exponents of the so-called Israel vision believe the white European race to be the offspring of the 'lost ten tribes of Israel'. In their monographs the Bible is treated as a prophecy of the present day, having made an exact forecast of the present role of this white race in the final stages of God's cosmic war against Satan. Studying these publications from the viewpoint of modern hermeneutics, allowing extensive space for the deconstructive role of the reader in the reading process, this article shows how every known fallacy in Biblical exegesis is found in one form or another in this literature. The conclusion is drawn that such arbitrary deconstruction is found with these authors, that it seems justified to describe the reading process found here as one in which destruction rather than deconstruction of the Biblical text takes place.
\end{abstract}

\section{KRITERIUM}

Om ' $n$ maatstaf te vind vir die beoordeling van ' $n$ bepaalde groep se gebruik van die Bybel, gebruik ons hier die standpunte van die moderne hermeneutiek. Die hantering van die Bybel word as 'n kommunikasiegebeure gesien. Daar is in die gebeure drie interaktiewe komponente aanwesig, wat elkeen ' $n$ integrale deel uitmaak van die totale kommunikasieproses: die skrywer, die gekodeerde teks en die leser. Die rol van die leser is nie die van 'n passiewe ontvanger nie, maar van ' $n$ aktiewe deelnemer. 'Die leser van 'n teks het onvermydelik ook 'n soort kreatiewe inset by die verstaan van 'n gekodeerde boodskap' (Deist \& Vorster 1986: 28). Na hierdie skeppende aandeel van die leser word soms verwys as 'dekonstruksie'. Die leesgebeure bestaan nie net uit die ontvangs van die outeur se gekodeerde boodskap nie, maar ook uit die leser se konstruering van denkinhoude tydens hierdie leesproses. By eksponente van dekonstruktiewe lees, soos Derrida, Miller en Fish, word die leser se aandeel oorbeklemtoon. Die gekodeerde teks word as redelik arbitrêr gesien. Taal bestaan volgens hulle uit toevallige tekens en het geen noodwendige verhou- 
ding tot die werklikheid waarna dit verwys nie. Omdat tekste dus ook arbitrêr is, sal die leser noodwendig oorgaan tot arbitrêre dekonstruksie van die teks. Die betekenis van ' $n$ teks berus daarom tot 'n groot mate uiteindelik by die leser. ' $n$ Meer gebalanseerde beskouing van dekonstruktiewe lees, kom voor by CS Lewis. Hy heg meer waarde aan die integriteit van die teks. Uit watter tekens die teks ookal saamgestel is, bly dit vir Lewis steeds tekens wat binne 'n historiese en intensionele konteks funksioneer. So behou Lewis "n balans tussen die komponente van die leesproses wat in die kakofonie van mededingende kontemporêre kritiese teorieë verlore gegaan het' (Edwards 1986: 213). Volgens Lewis se beskouing moet daar dus 'n aanwysbare korrelasie wees tussen die bedoeling van die historiese outeur, die tekswêreld soos dit uit die gekodeerde teks na vore kom en die leser se dekonstruksie vanuit sy lesersraamwerk.

Die kommunikasiegebeure behels dus meer as net die historiese konteks, literêre tradisie, genre of die Sitz im Leben waaruit die outeur die teks geskep het. 'A text's context means for the rhetorical critic the attitudinizing conventions, precepts that condition (both the writer's and the reader's) stance toward experience, knowledge, tradition, language, and other people'. (Wuellner 1987: 450). Die leesproses is 'n vorm '. . van aktiwiteit onskeibaar van die breër sosiale verhoudings tussen skrywers en lesers' (Eagleton in Wuellner 1987: 463). Bybellees is 'social discourse' (Wuellner 1987: 462). Dit bied nie geïsoleerde en tydlose antikwariese reste nie, maar 'products of a time of writing and a time of reading' (Fowler in Wuellner 1987: 463.)

Wanneer enige vertolking van die Bybelse literatuur dus beoordeel word, moet gevra word na die groter sosiale verband van die leesproses. Met ander woorde: wat is die verband tussen die dekonstruksie waarmee die leser vorendag kom, die wêreld van die teks en die geintensionaliseerde en gekodeerde bedoeling, ian die outeur? Dit word die maatstaf vir wetenskaplike lees: 'n Mens moet 'die konteks van die oorspronklike kommunkasiesituasie en die konteks waarin die teks later kommunikeer, ernstig neem en die twee situasies as korrektiewe op mekaar laat inwerk' (Deist, \& Vorster 1986: 29).

Hierdie uitgangspunt word gebruik om die publikasies te beoordeel van 'n groep outeurs wat opvallende ooreenkoms vertoon in hulle hantering van die Bybel en veral in hulle gemeenskaplike uitgangspunt. Een van die outeurs praat van hulle as 'die groep met die Israelvisie' (Hayes sa: 340). In hierdie artikel gee ons aandag aan die leserskonteks van die voorstaanders van die Israelvisie, hulle lesersperspektief en die 
tegnieke van dekonstruksie wat in hulle geskrifte voorkom. Omdat hulle voorkeur gee aan die $\mathrm{Ou}$ Testament, skynbaar vanweë die identifisering van groepe in sosio-etniese terme daarin, word ook op verwysings na die $\mathrm{Ou}$ Testament gekonsentreer. Uit hierdie gegewens kan die aard en graad van korrellasie tussen die oorspronklike kommunikasiesituasie en die konteks van waaruit hierdie outeurlesers met die Bybelteks kommunikeer, beskryf en beoordeel word.

\section{DIE UITGANGSPUNT VAN DIE ISRAELVISIE}

Die wesenlike uitgangspunt van die outeurs is die identifisering van die Wes-Europese blankes met die tien stamme van die Noorderyk Israel. Die inwoners van die Noorderyk is in die jaar 721 voor Christus in ballingskap na Asirië weggevoer deur Sargon II. Wat verder met hierdie ballinge gebeur het, word nie in die Bybelliteratuur meegedeel nie en is onbekend.

Die eksponente van die Israelvisie gaan egter van die spekulatiewe teorie uit dat hierdie tien stamme uit hul ballingskap uit Assirië ontsnap het en onder verskillende ander name deur die eeue deur Europa getrek en uiteindelik in die Westerse Nasies ontwikkel het (Neser sa: 12). Die Germane, Wes-Gote, Hunne en Vandale, wat Europa vanuit die noord-ooste binnegetrek het, was die afstammelinge van hierdie tien stamme van Israel (Swart sa: 31). Die groep van die Normandiërs het die Britse eilande ongeveer $1000 \mathrm{nC}$ binnegeval (Studiegroep Aktueel Windhoek - Raadsplan sa: 8). Armstrong, die 'vader' van hierdie visie, beskou die inwoners van Engeland en van die Verenigde State van Amerika gevolglik as die letterlike fisiese afstammelinge van hierdie tien stamme today, ... the House of Israel is In The Isles ...' (Armstrong 1967: 115).

Binne die Suid-Afrikaanse konteks word die Blanke Europeërs pertinent aangedui as die nasate van hierdie tien stamme. Hulle is die nakomelinge van die Israeliete aan wie die Woord en Wet van Yahweh toevertrou is (Deut 4: 19, Jes 51: 7), wat oor die wêreld versprei is en die rykdom van die aarde besit en benut (Gen 49, Deut 33), wat die hoogste gawes en vermoëns van hart het, wat die wêreld tot seën is (Miga 5), wat van alle ander onderskei is deur hulle Blanke vel, eenderse gelaatstrekke, ooreenstemmende kultuurgebruike en gewoontes (Neser sa: 26).

Hierdie beskouing kom in al die geskrifte van die aanhangers van 
hierdie standpunt voor. Dit is die een gemeenskaplike faktor wat te midde van alle onderlinge verskille steeds die dominante rol speel wanneer hulle die Bybel lees. Waar die Bybel as historiese geskrif uit die aard van die saak nie eksplisiet kan aandui watter groep, indien enige, honderde jare nadat dit geskryf is, met Israel geïdentifiseer moet word nie, is dit duidelik dat ons hier met ' $n$ baie prominente dekonstruksie van die Bybelteks te doen het. Die wesenlike vraag wat gestel moet word, is of daar in hierdie dekonstruksie 'n substansieerbare verband bestaan tussen die vertolking waarmee hierdie lesers vorendag kom en die bedoelings van die Bybelouteurs in so verre dit uit die gekodeerde Bybelteks afgelei kan word.

\section{DIE ESKATOLOGIESE LADING VAN DIE LEESGEBEURE}

Al die monografieë wat gelees is, het 'n baie sterk eskatologiese karakter. Die eksponente van die Israelvisie is deurgaans oortuig dat die hede die laaste dae van hierdie dispensasie verteenwoordig. Die hede is vir die skrywers die dae van voltooiing en finale vervulling. (Neser [1979]: 19). Die woorde van die boek Daniël (12: 8-10), en al die 'profesieë' in die Bybel, is selfs nie van betrekking op die tyd toe dit geskryf is nie, maar is alles vir vandag bedoel.

Vir die leesmetode beteken dit dus dat die historiese komponent van die gekodeerde outeursintensie kwalik ter sake is. Dit gaan hier primêr om die konteks van die leser en die hede. Dit is opvallend in die literatuur wat geraadpleeg is, dat daar uiters selde aandag gegee word aan die historiese situasie van die Bybelouteurs, die tipe literêre vorms wat gebruik is of die funksie van daardie literatuursoorte in die Bybelse materiaal. Dreigredes, byvoorbeeld, word summier as 'profesieë' gelees en beloftes as toekomsvoorspellings. So 'n leesmetode is normaalweg uitgelewer aan die willekeur van die leser. Hy ken aan die gekodeerde teks enige betekenis toe, net soos dit hom behaag. Wat egter verhoed dat hier sonder meer van willekeurige dekonstruksie van die teks gepraat kan word, is die oorweldigende pogings van die skrywers om hulle eie standpunte met Bybeluitsprake te identifiseer. Daar is ' $n$ volgehoue poging om Bybelse terminologie te gebruik om die eie gedagtes te verwoord.

So word die verwagtings wat vir die hede gekoester word, telkens uitgedruk in Bybelse terminologie. Die outeurs praat van die finale vervulling van die profete wat op hande is, die toenemende benoud- 
heid van Jakob, die nasionale ontwaking van Israel, die versameling en eenwording van Juda en Israel, die engele wat die uitverkorenes sal versamel, Israel wat sal terugkeer na hulle land en die wedergeboorte van die oorblyfsel van Israel (Studiegroep Aktueel Windhoek - Raadsplan sa: 12).

Naas die Bybelse terminologie word ook aspekte van die eskatologiese gesigshoek, waaruit baie van die Bybelliteratuur geskryf is, oorgeneem. Verskillende tipiese kenmerke van 'n eskatologiese wêreldbeskouing word in die monografieë teruggevind. By die skrywers skuil daar ' $n$ dringendheid om verborge kennis oor te dra. Die inligting dat die blanke die letterlike afstammeling van Israel is, moet dringend oorgedra word om die ... 'Wit Volk van Yahweh te voed met Waarheid en Kennis sodat hulle heupe omgord sal wees en hulle lampe aan die brand vir die Uur Van Middernag waarop ons afstuur voor die deurligtige dag van Yahweh en die lig van die daeraad op ons sal skyn' (Opperman 1986: 2, 3).

Ook die tipiese eskatologiese siening van 'n dualistiese kosmiese stryd en die finale botsing tussen goed en kwaad, kom hier voor: Satan het sy kanaal deur wie hy werk, naamlik die heiden, en God het sy kanaal deur wie Hy werk, naamlik Israel. Die stryd is 'n 'stryd tussen die saad van die slang en die Saad van die vrou (wat) verloop tot op die uiteindelike oorwinning en vestiging van die Koninkryk van God op aarde...' (Neser [1979]: 28).

Om die 'heidene' en 'Israel' van vandag te identifiseer, word 'n simbolies-letterlike tegniek gevolg. Die simboliese tegniek leen hom baie goed tot arbitrêre assosiasies volgens die leser se smaak. Die letterlike tegniek funksioneer nou binne die simboliese en verabsoluteer die gekose betekenis wat aan die simboliese toegeken is, as die enigste letterlike toepassingsmoontlikheid. So is die teen-Goddelike magte simbolies die nageslag van Esau, die afstammelinge van Edom; die Jode (Steenkamp sa: 8). Hulle het deur die ondertrouing van die Judeërs en die Idummeërs tot stand gekom (Studiegroep Aktueel Windhoek - Esau sa: 1). Jakob (Israel) is simbolies die vader van die Wes-Europese blanke. Die blankes en niemand anders nie, is die letterlike afstammelinge van die tien stamme. Hulle is in 'n eskatologiese stryd gewikkel teen die res. Die satan probeer hulle vernietig om so die wederkoms te verhoed, 'Daarom steek hy die nasies van die aarde op teen die blanke christen nasies van die weste' (Neser sa: 42).

Naas hierdie etniese identifisering, word ook van 'n ideologiese skema gebruik gemaak. God het Israel vir Homself gekies en die Satan 
het '. . . die Babiloniese opeenvolging van Volke gekies' (Neser [1979]: 30 ). Die volke wat deur die eeue teen God en sy volk te velde getrek het, word deur Babel versinnebeeld. Sedert Babel beskik hulle ook nog altyd oor die geldmag in die wêreld. 'Daar in Babel is die goud standaard meer as 2520 jaar gelede aangeneem, en vanaf daardie tyd tot vandag toe was dit die embleem en maatstaf van geld, waarde en rykdom' (Neser [1979]: 42). Hierdie geldmag is tans in die hande van 'n Joodsbeheerde liggaam bekend as die Illuminati. Hulle is die arm van die bose mag in die wêreld. Die 'regse' en 'linkse' magte van die wêreld vind hulle oorsprong in '. . J Jakob wat onder die gees van God gebore is en sy diensvolk is' en Esau '. . . die rooie wat onder die gees Satan gebore is en wie se nageslag die diensvolk van Satan is' (Eksteen 1980: 11). 'n Ideologie van linkse en regse magte, van etniese identiteit en bestaanskonflik, word dus hier getranspareer bo-oor 'n Bybels-eskatologiese visie van God en sy ewige heerskappy.

\section{DIE GEHEIME SLEUTEL TOT DIE SKRIF}

Hierdie eskatologiese benadering is nie sonder sy apokaliptiese moment nie. Die skrywers se pastiche van eie ideologie en Bybelse visie word as ' $n$ esoteriese openbaring gesien. Hulle maak daarop aanspraak dat sake wat die Bybel net vaagweg aandui, tans duidelik uitgespel kan word, danksy 'n nuwe 'openbaring' wat hulle ontvang het. Die opvallende resultaat van hierdie tegniek van 'overspecification' (Sire 1980: 62 ), is dat dit nie nuwe inligting aanbied oor God nie, maar oor die verborge identiteit van die nageslag van Israel. Die klassifikasie vergissing van misplaaste konkreetheid waar 'kontemporêre kerklike en teologiese denke te maklik as volledige Bybelse idees beskou word' (Van Aarde 1985: 568), kom hier voor. Die selfgesentreerdheid rondom eie Westerse kultuur en Blanke etnisiteit word tot die hartstuk van wat hulle noem die geopenbaarde 'Godsplan' verhef. Die soeke na eie identiteit by die Israel van die Bybel op verskillende gebiede, soos bloedverwantskap, geloofsverbondenheid, verbondstrou en etiese verantwoordelikheid, word by die gewaande nageslag van Israel vereng tot identiteit in bloot kultuur-etniese terme.

Die identiteit van die hedendaagse Israel is die belangrikste saak wat geopenbaar word. 'Die laaste verlore Skrifwaarheid wat nog geopenbaar moet word, is die identiteit van God se ware Israelvolk wanneer God die omhulsel oor die nasies kom verwyder (Jes 25: 7)' (Studiegroep 
Aktueel Windhoek sa: 9). Dit word geopenbaar dat die 'Westerse Blanke Protestantse nasies van vandag die letterlike afstammelinge van daardie tien stamme van Israel is' (Neser sa: 3). Hierdie 'openbaring' funksioneer as die 'Master Key to the Prophecies' (Armstrong 1967: 20).

Terwyl die identifisering van Israel met die Blanke die eksklusiewe sleutel tot die Bybel is, is die Bybel eweneens die ekskulsiewe besit van hierdie hedendaagse Israel. Histories staan dit '. . . vas dat die Bybel, Ou en Nuwe Testament, bedoel is slegs vir Israel en vir geen ander volk onder die hemel nie' (Neser sa: 14). Die Skrif toon ook aan 'dat God net besig was met Israel en dat Jesus slegs aan Israel belowe was' (Hayes sa: 138). Soos by alle eskatologies-georiënteerde groepe in die geskiedenis, lei hierdie siening dan ook tot eksklusiwisme en verabsolutering in die groep se denke en funksioneering: 'Die essensie van die Bybelboodskap is dus dat Israel hom moet afsonder en afskei van die volke' (Neser sa: 29).

\section{ESKATOLOGIESE DETERMINISME}

Wanneer die eksponente van die Israelvisie die eksklusiewe bestaan van die wes-Europese Blanke as Israel sien en dit beskou as die uitsluitlike terrein van God se beloftes en verlossing, moet daar krities gevra word na wat hier in die leesproses gebeur. ' $n$ Leesmetode word hier gevolg waar getrag word om die maksimum identifikasie tussen die Israel na wie die Bybel verwys en die eietydse Blanke 'Israel' te skep. Daardeur ontstaan een van die mees basiese leesfoute, wat ressorteer onder '... fallacies arising from omission of distanciation' (Carson 1986: 136). Die Bybelse teks word so met die hedendaagse leefwêreld geïdentifiseer dat dit op geen wyse met sy eie intellektuele en kulturele raamwerk in verband gebring word nie; dit word vanuit 'n totaal andertydse en Bybels vreemde verwysingsraamwerk gelees. Alle verskille word geïgnoreer en daar ontstaan 'world-view confusion' (Sire 1980: 26). Misplaaste konkreetheid tree in wanneer hierdie hedendaagse 'Israel' totaal met die Bybelse Israel vereenselwig word. Meer nog, 'n gesigshoek kom na vore waarin die bestaan en handhawing van hierdie moderne 'Israel' as die uitvoering van God se wil gesien word. In terme van die 'Godsplan' beteken dit dat God se toekomstige optrede staan of val by die voortbestaan van hierdie groepe mense. Hermeneuties en teologies kom daar dus uitsprake na vore wat kwalik nog met die gekodeerde teks korreleer. Hierdie beoordeling word duideliker wan- 
neer gelet word op die wyse waarop hulle Israel as sentrale tema van die Bybel hanteer.

God het, volgens die eksponente van die Israelvisie, deur die loop van die Bybelse geskiedenis ' $n$ bepaalde pad met Israel geloop. Daardie geskiedenis is nog nie afgehandel nie. Die geheel van hierdie geskiedenis, vanaf Abraham tot in die hede, is deur God gedetermineer en staan bekend as sy 'Master Plan' (Armstrong 1967: 1), sy 'Godsplan' (Neser [1979]: 28), Raadsplan of diensplan. In die Bybel word hierdie '. . . voorafbepaalde plan van Jahweh bekend aan die wat Hom ken, vertrou en sy Woord bestudeer (Vd Gaag 1985: 1).

Omdat God ewig en onveranderlik is, is hierdie plan ook onveranderlik. Die Bybel is as '... die ewig, onveranderlike, onfeilbare woord van God' (Aksie Aktueel Perdekop sa: 3) noukeurig rondom hierdie tema opgebou. Neser is daarom op fundamentalistiese wyse oortuig daarvan dat 'die Bybel volkome ineenskakel' (Neser [1979]: 44). Vir Hayes is elke woord '. . . deur God geïspireer en pas net op daardie plekkie waar dit oorspronklik geskryf is ...' (Hayes sa: 201). 'n Biblisistiese rekonstruksie word dus uit die Bybel van hierdie 'Raadsplan' gemaak. Dit word dan weer as die basiese verklaringsmodel gebruik van waaruit na samehang en betekenis in die Bybel gesoek word. Daar is selfs ekstase by die outeurs wanneer hulle aan die hand van hulle 'plan' die samehang gevind het: '. . . wanneer jy die Bybel reg verstaan, dan voeg alles inmekaar soos 'n pragtige skildery waarop selfs die fynste besonderhede aangebring is ...' (Neser [1979]: 53).

Dit is belangrik vir ons begrip van die denkwêreld van hierdie outeurs om hier raak te sien dat die Bybel in hulle denke nie net eienskappe met God deel nie (ewig, onveranderlik), maar dat die nukleus van die Bybel, die 'Godsplan', so totaal met God geïdentifiseer word, dat Bybel, God en Raadsplan, nie net uitwisselbare terme word nie, maar dat God selfs afhanklik gestel word vir sy bestaan van die voortgang en uitvoering van hierdie plan.

\section{DIE BYBEL IS 'PROFESIE'}

Om te kan aantoon dat die Bybelse plan van God die ware identiteit van Israel openbaar as die wes-Europese Blanke van vandag, vereis bepaalde leestegnieke. Die belangrikste vereiste is dat die Bybel nie vanuit die konteks van die verlede verstaan moet word nie, maar vanuit die konteks van die hede. Die leserskonteks moet dus totaal domineer. 
Dit kom in effek daarop neer dat aspekte van die betekenisveld van 'n begrip of woord uit die leserskonteks geneem word en op die Bybelteks geprojekteer word. Die Bybelteks word gevul met die leser se gedagteinhoude, maar met behoud van die Bybelse terminologie. Op prekritiese wyse word dan verklaar dat die Bybel destyds al gesê het wat die leser vandag onder die Bybel se begrippe verstaan. In aansluiting daarby beskou die eksponente van die Israelvisie ongeveer een derde van die Bybel as 'profesie'. Volgens hulle het dit akkurate voorspellings gemaak oor die identiteit van die Israel van vandag. Alles wat as 'profesie' gesien word, word gevolglik as apokaliptiese literatuur hanteer. Dit word simbolies-letterlik toegepas op die hede. Dit beteken dus dat die Bybel nie net vanuit een verabsoluteerde gesigshoek gelees word nie, maar ook dat die eie literatuursoorte van die Bybel geïgnoreer word en dat alles as letterlike voorspellings gelees word. Hierdie soort hantering van literatuur gaan gewoonlik gepaard met versuim om die onmiddellike literêre konteks in ag te neem by die leesproses. (Sire 1980: 52)

Die derde van die Bybel wat uit'. . . infallible Prophecy - writing the history of future events ...' (Armstrong 1967: 2) bestaan, vorm vir die outeurs van die Israelvisie die wesenlike van die Skrif. Een rede hoekom die ander gedeeltes weggelaat kan word, is die Biblisistiese siening dat Jesaja van die profete eerste in die Bybel staan en dus die oudste profeet is, wat 'in sy eerste hoofstuk reeds (Jesaja 1: 11, 13), die brandoffers en die voorafgaande afgeskaf het' (Eksteen 1980: 55). 'n Ander rede warom die res buite rekening gelaat kan word, is dat die toekomsgerigte profesieë vir hierdie selfgesentreerde sienswyse, die enigste gedeelte is wat die hede raak.

In hierdie 'profesieë' word dikwels met 'n esoteriese 'dual fulfillment' (Armstrong 1967: 134) gewerk. Sommige profesieë is reeds vervul, maar die belangrikste daarvan is nog uitstaande. So was Levitikus 26 '. . . a warning to those of Moses' day - but its final fulfillment ... has taken place - and is now taking place - in our time' (Armstrong 1967: 134). Efesiërs 2: 11-22 is 'n gedeeltelike vervulling van Esegiël 37: 22. Die 'volle klimaks' word eers bereik 'in die Vredesryk' (Steenkamp sa: 16)

'n Manier om te onderskei tussen reeds-vervulde en uitstaande profesie, is om te vra of dit wat daar geskryf staan alreeds letterlik in die leser se tyd gebeur het. Indien dit nog nie in die geskiedenis letterlik gebeur nie, word dit as uitstaande profesie beskou wat beslis nog sal gebeur. Die 'beloftes' van 2 Samuel 7: 13 is nie in Christus vervul nie, omdat daar nie 'n letterlike troon was in Jesus se tyd in Jerusalem nie en 
die troon moet tog letterlik in Jerusalem staan. Dit is dus 'n profesie vir die wederkoms. Die verskillende Skrifgedeeltes wat na Esau of Edom verwys, het almal nog toekomstige betekenis, omdat Esau simbool is van die satan en die geleentheid waarop hy God se volk in die hakskeen gaan byt het nog nie gekom nie (Studiegroep Aktueel Windhoek sa: 23).

In ander gevalle word aangeneem dat ' $n$ bepaalde uitspraak slegs op een bepaalde saak in die huidige wêreld letterlik toegepas kan word. Daar bestaan dikwels ander, meer natuurlike verklarings vir ' $n$ bepaalde uitspraak. Dit word egter buite rekening gelaat ten gunste van ' $n$ verklaring wat meer in lyn is met die leser se eie uitgangspunte (vgl Sire 1980: 96). Sulke direk toepasbare uitsprake word by die Israelvisie as 'profesieë' beskou. Joël 2: 5 en Habakuk 1: 8, 9 verwys na vliegtuie, Joël 2: 30 na die atoombom, Esegiël 38: 2 se ros is Rusland en Nehemia 2: 4 se strydwaens is niks anders nie as '. . motorvoertuie wat die eerste keer in 1914-18 vir oorlogvoering gebruik is' (Eksteen 1980: 22). Die Derde Wêreldoorlog word letterlik voorspel in Esegiël 38, 39 Joël 3, Sefanja 1: 14-18, Sagaria 14: 1-13, daarom moet dit as Satan se finale offensief om Israel te vernietig, verstaan word (Studiegroep Aktueel Windhoek - Raadsplan sa: 11). Gedeeltes soos Sefanja 3: 10-13, Levitikus 26: 33, 1 Konings 14: 15 en Esegiël 5: 10, toon aan dat God sy volk na die suidpunt van Afrika sal verstrooi en daarom moet die volk 'net in die suidpunt van Afrika wees, anders kan 'n hele klomp profesieë nie vervul word nie ...' Sefanja 3: 10 sê tog uitdruklik dat die verstrooide volk van die onderkant van die Zambezi as ' $n$ volk sal terugkeer van Palestina' (Hayes sa: 24).

Nog 'n verabsoluteringstegniek wat gebruik word, is om gedeeltes waarin die Bybelskrywers onder andere na die toekoms verwys, in hulle geheel as 'toekomsprofesie' te lees. Die toekomende gebeure word dan op geen ander tyd in die geskiedenis betrek nie as slegs net op die leser se tyd. Terwyl alles wat oor die eeue heen gebeur het sedert die Bybelgedeeltes geskryf is, die toekoms vir daardie tyd was, word op eklektiese wyse slegs die huidige gebeure as die bedoelde tyd begryp. Uitdrukkings soos 'aan die einde van die dae' of 'die laaste dae' word konsekwent op die hede alleen toegepas. In Deuteronomium 31 het Hayes vir homself uitgemaak dat dit oor die laaste dae gaan. Al bestaan hoofstuk 32 nou uit gedeeltes oor die verlede (verse 16-20) en gedeeltes oor die toekoms (vers 20 en verder) neem hy eenvoudig aan dat alles 'eindprofesie' is (Hayes sa: 78). Jeremia 7 en 8, bevat skeldredes waarin die inwoners van Jerusalem gewaarsku word om hulle valse vertroue op die tempel te laat vaar. Hierdie gedeeltes word eenvoudig gelees asof 
dit toekomsprofesieë is. Hulle voorspel die toekoms van Israel vir vandag (Studiegroep Aktueel Windhoek - Esau sa: 5).

\section{7. 'N ONDERSTEUNENDE TYDSKEMA}

Die oortuiging dat die Bybel profeties en van direkte toepassing is op die hede, word verder ondersteun met 'n noukeurig uitgewerkte chronologie. Die mees algemene model waarmee gewerk word, is dié van 'n sesduisendjarige tydperk. By sommige outeurs bestaan die oortuiging dat daar ook nog ' $n$ duisendjarige vrederyk aan die einde van daardie geskiedenis lê, sodat dit 'n totaal van seweduisend jaar behels.

By die Studiegroep Aktueel Windhoek is hierdie chronologie uitvoerig uitgewerk. God se Raadsplan strek oor seweduisend jaar. Tussen die begin (Gen 1: 1) en die skepping (Gen 1: 2) het miljoene jare verloop. Vanaf Adam tot by Jesus het ongeveer vier duisend jaar verloop. Genesis tot by Josua behandel die tyd tussen vierduisend en eenduisend voor Christus. Die historiese materiaal vanaf Rigters tot Ester asook die tydsgebonde verhalende gedeeltes van die profetiese boeke, handel oor die tydperk van ongeveer eenduisend tot vierhonderd voor Christus. Die toekomsgerigte profesieë in die profetiese boeke handel oor die tydperk duisend voor Christus tot drieduisend na Christus: '. . . dit behels die verloop van Israel se geskiedenis vanaf hulle vestiging in die land Kanaän as die koninkryk van Dawid tot die hervestiging van die Koninkryk van God op aarde, die duisendjarige vrederyk en die finale oordeel' (Studiegroep Aktueel Windhoek-Raadsplan sa: 1-2). Die Duisendjarige vrederyk sal volgens hierdie berekening teen ongeveer tweeduisend na Christus aanbreek, dit wil sê in hierdie tyd.

Om by hierdie berekenings uit te kom, word twee verskillende tegnieke gekombineer: die letterlike en die simboliese uitleg. Dit is 'n metode wat baie naby kom aan ' $n$ leesfout wat Sire 'collapsing contexts' (Sire 1980: 58) noem. Gedeeltes wat nie direk met mekaar te doen het nie, word gelees asof hulle in direkte verband met mekaar staan. By die eksponente van die Israelvisie word die letterlike uitleg gebruik om aan te toon dat die Bybel 'n presiese aanduiding gee van die verloop van gebeure. Terwyl die Bybelse getalle letterlik behou word, word die eenhede waarmee die Bybel werk, simbolies uitgelê. Die algemene konsensus is dat die ballingskap tweeduisend vyfhonderd en twintig jaar sal duur. Die einde van die ballingskap val saam met die voltooiing 
van die sesduisend jaar. Dit moet alles in hierdie tyd gebeur. Om by hierdie slotsom uit te kom, word die dreigement van God in Levitikus $26: 18,21,24,28$ om Israel sewevoudig te straf, gelees as ' $n$ verwysing na 'sewe tye'. Levitikus 26 word direk op die ballingskap betrek en gevolglik verstaan as 'die groot 7 tye strafgerig' (Opperman 1986: 22). Een tyd is volgens Genesis 7: 11 drie honderd en sestig dae, sodat sewe tye dus tweeduisend vyfhonderd en twintig dae is. Volgens Esegiël 4: $4-6$ is in die geval van God se strafgerig teen Israel '. . . elke dag 'n strafgerig tydperk van een jaar' (Opperman 1986: 23), sodat die genoemde aantal dae as jare gelees moet word. Volgens die dag-vir-'n-jaar beginsel van Numeri 14: 34, kom hierdie tyd wat die strafgerig sou duur, neer op ' $n$ tyd van tweeduisend vyfhonderd en twintig jaar (Armstrong 1967: 144). Aangesien ons hier met Bybelse profesie te doen het wat met begrippe soos 'die einde van die dae' werk, moet die einde van hierdie tydperk betrek word op die dae wat reg aan die einde van alles is en dit is die hede.

In die opinie oor presies wanneer die ballingskap ten einde sal kom, bestaan daar verskil van mening. Volgens Armstrong se berekening kom dit uit op $1800 \mathrm{nC}$ toe die geboortereg volkere, Engeland en Amerika, grootmoondhede begin word het. Volgens Neser is dit in ooreenstemming met Lukas 21: 24, die jaar $1917 \mathrm{nC}$, toe Allenby Jerusalem van die nasies bevry het - presies tweeduisend vyfhonderd en twintig jaar nadat Nebukadnesar dit in $603 \mathrm{vC}$ die eerste keer beleër het (Neser [1979]: 25).

Die strategie wat hier gevolg word, is die van 'logiese afleiding'. Die Bybel word gesien as ' $n$ profetiese boek wat die verlede een honderd persent korrek voorspel het. 'Deur die Profeet Daniël het God selfs die presiese jaar aangedui waarin Christus gedoop sou word' ook die 'presiese tyd waarin Hy gekruisig sou word' (Neser [1979]: 4). Daarom is die Godsplan, soos dit aan hulle uit die Bybel geopenbaar is, ook absoluut korrek. Daniël 2 gee byvoorbeeld,

... vir ons in breë trekke in profetiese vorm die geskiedenis van al die heidense nasies met betrekking tot Israel, vanaf die tyd van Nebukadnesar tot met die wederkoms van Christus (Neser [1979]: 40).

Waar dit egter nog duideliker word dat dit in der waarheid hier gaan om die sanksionering van die letterlike Israelteorie deur middel van Bybelse gesag, is wanneer die Bybelse geskiedenis aan spekulatiewe datums en teorieë verbind word. Die Koninkryk van God is '. . . in 1487 
vC by berg Sinaï . . gekonstitueer (Eks 19: 3-6)' (Neser [1979]: 33). God het in die jare 585-3 vC, tydens die regering van Nebukadnesar, onder Jeremia sy koninkryk oorgeplaas na die Weste waar dit in die Britse Eilande en Wes-Europa gevestig geraak het. (Neser [1979]: 35). Om by die bedoelde moderne datum uit te kom, word dit as vertrekpunt geneem en in die tyd teruggereken. Dat alles op die lange duur maar eintlik gaan oor die sanksionering van die Israelvisie en die legitimering van hulle aansprake, word ook duidelik in Neser se kommentaar op die boek Daniël. Die toespitsing van die boek self op die omstandighede van die tweede eeu voor Christus word geïgnoreer en die inhoud van die boek betrek op die hede, sodat alles as ' $n$ 'profesie' van die hede verstaan word.

\section{DIE DOMINANTE ROL VAN DIE LESER SE LEEFWÊRELD}

Die dominante rol van die tyd en ruimte waarin die leser self leef, is opvallend in die verloop van die leesproses. Vanuit die raamwerk van die leser word eietydse inhoude geïdentifiseer en direk oorgedra op die antieke Bybelse literatuur. Die Bybelse literatuur, gevul met die moderne inhoude, word dan as 'profesie' weer direk teruggelees na die leser se eie leefwêreld. Die leesproses verloop dus in 'n sikliese gang. Alles kom neer op die sentralisering van die leser, sy tyd en sy omstandighede. Dit word duidelik uit Armstrong se verklaring dat '. . . these prophecies were written for Our People Of Our Time, and for no previous people or time. They pertain to world conditions of Today, and could not have been understood until today' (Armstrong 1967:6). Die letterlike fisiese omstandighede van vandag staan in die fokuspunt van alles.

Die gegewens van die leser se leefwêreld word so volledig met die literatuur van die Bybel geïdentifiseer dat daar later geen ruimte meer gelaat word vir enige ander betekenisskakerings as net die wat die leser in gedagte het nie. 'Profesieë', soos Jesaja 18: 1-7, Esegiël 20: 46-48, Sagaria 10: 1-7 en 12: 6, Sefanja 3: 10 en Jeremia 24, word deur Van der Gaag (1985) hanteer as profesieë waar van die eindvervulling in ons tyd sal plaasvind en almal betrekking het op Suid-Afrika. So dui Jesaja 18: 1 se vlerkgegons op krygsgedruis in Suid-Afrika, die riviere van Kus is die Zambezi, Cuando, Okavango, die boodskappers van 18: 2 is die swart terroristeleiers. 'Die eerste vers van Jesaja hoofstuk 5 begin met 
die planting van ons volk in 1652 . Die laaste vers eindig waar die Derde Wêreldoorlog in sy volheid woed' (Hayes sa: 228).

In hierdie leesproses word die woordjie 'net' opvallend dikwels gebruik. Dit is natuurlik 'n meganisme om alle ander moontlike identifserings uit te skakel. Let byvoorbeeld op hoe alternatiewe verklarings met die woord net in die volgende beredenering uitgeskakel word: 'Beide Sefanja en Jesaja het voorspel dat God se volk aan die einde van die dae in die onderkant van die Zambesie sal wees. Hulle kan net Suid-Afrika ingedagte gehad het' (Hayes sa: ongenommerd).

'n Interessante verskynsel wat by Hayes voorkom, maar ook kenmerkend is van die meeste outeurs uit hierdie kring, is wat 'n mens ' $n$ tweede-fase identifikasie kan noem. Die aanname dat Sefanja en Jesaja van die gebied anderkant die Zambezi gepraat het is 'n eerste identifikasie. Dit word dan onkrities en sonder verdere oorweging as uitgemaakte saak verder hanteer. Dit geld as 'n onomstootlike waarheid waarop ' $n$ tweede argument gebou word: dit is Trans-Zambezi en van al die moontlikhede in daardie gebied kan dit net Suid-Afrika wees. Die Bybel sê dit is Trans-Zambezi (veronderstelling een). TransZambezi kan net Suid-Afrika wees (veronderstelling twee). Die Bybel sê dit is Suid-Afrika (afleiding).

Wanneer daar wel ruimte gelaat word in die uitleg vir simboliek, is dit niks anders nie as 'n verskansde letterlikheid. Daar is in die Bybel 'sogenaamde woordsimbole, wat deur die hele Bybel heen dieselfde onveranderlike betekenis behou...' (Bybelstudiekring Plumstead 1987: 1). Hoe hierdie simboliek met onveranderlike betekenis letterlik funksioneer, kan aangetoon word in die Studiegroep Aktueel Windhoek se eklektiese studiestuk oor Esau versus Jakob. Esau word hier simbolies vereenselwig met Edom en met die Edummeërs, met slange, basaliske en die duiwel. Die giftige slange wat God volgens Jeremia 8: 17 onder Juda stuur om hulle te pik word deur die studiegroep nie as fisiese slange, of as aanduiding van die ballingskap gesien nie, maar as die infiltrering van Edom om Juda te verbaster (Studiegroep Aktueel Windhoek-Esau sa: 4). Simbolies word hier, volgens hulle, verwys na die letterlike poging om rassesuiwerheid deur gemengde ondertrouing uit te wis. Jeremia 7 en 8 se waarskuwing aan die inwoners van Jerusalem teen valse vertroue op die tempel en die wet, lees die studiegroep as voorspellings van die verre toekoms. Op eklektiese wyse word al die ander gegewens wat in die teks ingesluit is, soos hulle vrouens wat aan ander gegee kan word, hulle grond wat aan nuwe eienaars oorgedra kan word, en so meer, geïgnoreer. 'n Leestegniek 
word gevolg van 'selective evidence', naamlik: 'to select only part of the evidence, prematurely construct a grid, and so filter the rest of the evidence through the grid that is robbed of any substance' (Carson 1986: 99). Slegs ' $n$ deel van die getuienis in Jeremia is uitgekies en die hele gedeelte is vereng tot ' $n$ voorspelling van die rol van Edom in die toekomstige gebeure.

\section{VERABSOLUTERING VAN DIE LESER}

Die doel agter die letterlike toepassing van die Bybel op die hede, is om geen sweem van twyfel te laat dat die wes-Europese Blanke die Bybel se Israel is nie. Enige geestelike of simboliese toepassing sou die moontlikheid inhou dat Israel in ander terme as die letterlike, fisiese of etniese definieer kan word. Van daar kom die driftige afwysing om Israel geestelik te verstaan. Die aanhangers van die Israelvisie is eenstemmig in die standpunt dat dit in die Bybel, Ou en Nuwe Testament, slegs om 'n letterlike nasionale entiteit Israel gaan '. . . en geen ander volk onder die hemel nie' (Swart sa: 14). Soos die ou verbond 'alleen gesluit is met die volk Israel toe Yahweh hulle uit Egipteland uitgelei het ...' (Neser sa: 17) en soos die troon van Dawid 'n letterlike troon was en die belofte aan hom ewige heerskappy oor die letterlike twaalf stamme van Israel was, so is die Israel van die Nuwe Testament die fisiese en letterlike nasate van die volk wat in die $\mathrm{Ou}$ Testament uitverkies is. Daarom word daar ook '... 'n letterlike herstelde nasionale Israel as kern ...' van God se Koninkryk verwag '. . . wat onder die leiding en beskerming van Christus sal staan' (Neser [1979]: 24).

Enige poging om Israel nie letterlik as Blankes te verstaan nie, maar dit te vergeestelik, is volgens die outeurs 'n on-Bybelse dwaling. Dit hou bepaalde wesenlike gevare in:

dit maak die Skrif se oorgang van die Ou Testament na die Nuwe Testament onverstaanbaar en die beloftes ò belaglik òf onverstaanbaar. Dit maak die wonderlike onveranderlike plan van ons Vader planloos en veranderlik (Neser sa: 8).

Dit is 'een van die slimste uitdenksels van die Satan om die ware Israel te vernietig en te laat verdwaal' (Neser sa: 13). Dit probeer die wederkoms van Christus te verhoed deur God se volk tot niet te maak (Studiegroep Aktueel Windhoek-Esau sa: 28). 'Die oorspronklike ver- 
bond word verwerp en 'n nuwe testament word opgetrek' (Weich 1986: 2).

Vergeesteliking van die begrip Israel sou deur die nie-Israeliet Konstantyn in $325 \mathrm{nC}$ ingevoer wees (Bybelstudiekring Plumstead sa: 3). Vergeesteliking behels die volgende: '. . . uitverkiesing van die volk word verander na uitverkiesing van die gelowige - genadeverbond met almal - ipv nuwe verbond met Israel - geestelike koninkryk ipv God se letterlike Koninkryk op aarde...' (Studiegroep Aktueel WindhoekRaadsplan sa: 9). Dit beteken om aan te neem '. . . dat almal wat glo kinders van Abraham is ...' (Neser sa: 13), . . . dat almal ongeag kleur of ras lid van die kerk sal word ...' (Bybelstudiekring Plumstead sa: 3), dat die begrip Israel vergeestelik het en op die kerk oorgegaan het (Steenkamp sa: 8 ) en dat Israel uit' . . vreemdvolkiges of vreemdrassige mense bestaan ...' (Swart sa: 21). Enige afwyking van 'n letterlike toepassing van Israel hou dus vir hierdie mense die bedreiging in dat dit hulle teorie in diskrediet kan bring.

\section{NIE DIE JODE NIE}

'n Ernstige bedreiging vir die teorie van die Israelvisie, is die standpunt dat daar ' $n$ verbintenis is tussen die huidige Jodendom en die Bybelse Israel. Daarom word met intensiewe heftigheid ontken dat die mense wat vandag as Jode bekend staan, identies is met die Israel van die Bybel. Drie redes word aangevoer waarom die Jode nie Israel kan wees nie.

Die huidige vorm en betaanswyse van die Jode stem volgens hulle in die eerste plek, nie letterlik ooreen met wat van Israel gesê word nie. Die Jode is '. . . net een nasie, en een enkel stam' (Eksteen 1980: 18) en kan dus nie die menigte van nasies wees wat God letterlik volgens Genesis 17 aan Abraham beloof het nie. God het aan Jakob (Israel) belowe dat sy nasate ' $n$ menigte van nasies sal wees en konings uit hulle sal voortkom (Gen 35: 11). Dit kan nie die Jode wees nie 'Want hulle is net een nasie en het nooit konings gehad nie' (Pelser sa: 1). Buitendien beredeneer Armstrong: '. . . we must face the astounding fact that our white, English-speaking peoples - Not The Jews - have inherited the national and physical phases of those Promises ...' (Armstrong 1967: 15).

Die tweede rede is van etnies-historiese aard. Die huidige Jode is '. . . 'n basternageslag voortspruitende uit die stam van Juda' (Studiegroep 
Aktueel Windhoek - Esau sa: 7). Hulle'. . . is maar ' $n$ klein gedeelte van die nakomelinge van Juda wat maar net een van die twaalf seuns van Jakob was' (Neser sa: 27). Die Jode is mense wat na die ballingskap Palestina binnegesypel het en as Jode bekend staan (Swart sa: 34). Hyrkanus het in $125 \mathrm{vC}$ die Edomiete by die Judeërs ingelyf en so het ' $n$ bastergeslag tussen ' $n$ deel van Juda en Edom ontstaan. Hulle is die voorgeslag van die huidige Jode (Studiegroep Aktueel Windhoek-Esau sa: 7).

Die derde rede skakel weer met die sleutelrol van die 'openbaring' dat die Blankes Israel is. 'Die Jode is nie en was nog nooit God se volk Israel nie' (Opperman 1986: 10). Om dit te besef 'Is Baie Belangrik Vir Die Korrekte Begrip Van God Se Woord. Hieruit ontspring geweldige misleiding en baie waninterpretasie van Gods Woord' (Studiegroep Aktueel Windhoek Esau-Jakob sa: 7). 'Die Bybel sal tot 'n groot mate sover dit Gods Plan met die wêreld betref, 'n geslote Boek bly, solank as die leringe en Profesieë sover dit Israel betref, alleen op die Jood soos hy vandag is, toegepas word' (Neser sa: 12).

\section{BEREDENERING DAT ISRAEL BLANK IS}

Dit is by die aanhangers van die Israelvisie ' $n$ vanselfsprekendheid dat Israel tot die Blanke ras behoort: 'Die Israeliete is witmense' (Eksteen 1980: 54). Israel van die Bybel was volgens hulle blank en daaruit volg tog logies dat die Wes-Europese Blanke die nasate van Israel is. Hierdie identifisering word veral gesien in die formulerings waar die Blankes genoem word en die Bybelse Israel direk daarnaas geplaas word, byvoorbeeld: Suider-Afrika is '. . . die laaste Blanke (Israel) vesting in donker Heidense Afrika' (Neser [1979]: 16). Esau of Edom voer die stryd teen Israel en Israel is '. . . ons volk en Blanke Protestantse Kerke' (Studiegroep Aktueel Windhoek-Esau sa: 23). In sommige gevalle word die kwalifikasie 'Protestants' ook bygevoeg. Hoekom die moderne Israel ook Protestants moet wees en hoekom Westerse nasies wat oorwegend Rooms-Katolieke is, uitgesluit word, is onbekend. Die aanname van die Blankheid van Israel word met verskillende tipes argumente ondersteun. Die redenasiepatroon wat gevolg word, kom op 'n tipe boemerang-argument neer. Eienskappe van die Blanke Westerling word geïdentifiseer en as uitgangspunt gebruik. In die Bybel word gesoek na woorde of uitdrukkings wat met hierdie eienskappe in verband gebring kan word. Daaruit word met 'associative jumps' 
(Carson 1986: 117) afgelei dat Israel ook in alle ander opsigte identies was met vandag se Westerlinge. Die argument voltooi die kringloop wanneer afgelei word dat, indien Israel Blankes was en die lesers is Blankes, dan is die lesers mos die huidige geslag van Israel.

Argument een: Wat Israel letterlik kwalifiseer as God se volk, kom ook letterlik voor by die blanke westerling. 'Die nasie of nasies dus wat Sy Lof Verkondig en wat Sy Getuies is en Wat Sy werk doen (dus sy kneg is), moet letterlik Israel wees'. (Die Jode doen dit nie en hulle is dus nie die Israelvolk nie.) 'Die blanke westerse protestantse nasies, alhoewel in 'n teruggevalle toestand, verkondig tog die lof van die ewige waaragtige God en van Sy Seun Jesus die Christus. Hulle druk en versprei die Bybel, stuur sendelinge uit, erken die Godheid as die Opperste gesag, en so meer' (Neser sa: 23). Hierdie argument begin weer eens by dit wat die westerling kenmerk, soek dan raakpunte in die Bybelse uitdrukkings en vul daardie begrippe met hierdie moderne inhoude. Sodoende word dit maklik om by die moderne westerlinge eienskappe raak te sien wat hom met 'Israel' identifiseer.

- Argument twee: Die Bybel beskryf Israel in terme wat uitsluitlik toepaslik is op die blanke westerling. Esegiël 36: 32 sou verklaar dat Israel kan bloos. 'Israel was en is dus ' $n$ volk wat bleek kan word en kan bloos, met 'n blanke vel en blosende rooi wange en lippe. Hierdie eienskappe is eie aan die blanke westerse nasies' (Swart sa: 32).

- Argument drie: Bybelse begrippe en woorde uit ander literatuur, selfs al verwys dit na geografiese gegewens, sou ook daarna verwys dat Israel blank is. 'Die huis van Jakob het 'n verskeidenheid name. Een is Libanon, die landstreek vanwaar Jakob se moeder en vroue afkomstig is, en Libanon beteken blank en Laban beteken blank; (Hofmeyr sa: 1). Dat die Israeliete blanke afstammelinge was van Abraham, Isak en Jakob word bewys uit die Genesis apokrief van Qumraan waarin Sara se witheid beskryf word (Opperman 1986: 15).

- Argument vier: Uit die eskatologiese ontwerp van die wêreldgeskiedenis word God se mense met die blanke geïdentifiseer. Satan probeer die Tien Stamme vernietig om die wederkoms van Christus te verhoed. 'Daarom stook hy die nasies van die aarde op teen die blanke Christen nasies van die weste' (Neser sa: 21).'Israel van die Bybel was blankes net soos $u$ en ek terwyl die kinders van die Bose, die krom en verdraaide geslag, anderskleurig was' (Swart sa: 31). 
Kennis van die kosmiese stryd tussen God se fisiese nageslag en die fisiese nageslag van Satan is van groot belang: 'Via hierdie Skrifwaarheid identifiseer ons die familie van God op aarde as sy blanke Adamitiese ras' (Studiegroep Aktueel Windhoek-Raadsplan sa: 1).

\section{GEOGRAFIESE IDENTIFISERINGS AS BEWYSVOERING}

Ook die geografiese identifisering van die woonplek van die nageslag van Israel is ' $n$ baie belangrike strategie in die verkondiging van die Israelvisie. Hier word veral van ongespesifiseerde verwysings na gebiede en windrigtings in die Bybel gebruik gemaak. Die vergissing van 'overspecification' (Sire 1980: 62) kom hierin oorvloedig voor. Wat in die Bybel slegs vaagweg aangedui word, word met hedendaagse geografiese kennis haarfyn uitgelê. 'Ten noordweste van Palestina', kan byvoorbeeld Turkye of Griekeland of Switserland of Engeland wees. Almal kan kwalifiseer. Selfs Siprus, wat boonop ook nog ' $n$ eiland is. Vanweë die vooringenome Israelteorie egter, word slegs Engeland as 'n moontlikheid beskou.

In ooreenstemming met die teorie van die trek van die tien stamme van die noorderyk, word Rusland as die eerste lokaliseringspunt .aangedui. Jeremia 23: 8 en 3: 18 verwys na Rusland as die agterhoeke van die noorde. Dit is via Rusland dat die tien stamme oor wes-Europa moes versprei (Eksteen 1980: 19). Vandaar het hulle na wes-Europa getrek. 2 Samuel 7: 10 se 'bestemde plek' van Israel is die kuslande en eilande (Jesaja 24: 15; 11: 11) noord-wes van Palestina - lande wat vandag bekend staan as wes-Europa. Terwyl hy ander aanduidings in Jesaja 24: 15, soos 'die lande van die son', ignoreer, besluit Armstrong dat hierdie teks net na die Britse Eilande kan verwys. Volgens Hosea 12: 1 'Ephraim followeth after the east wind. An east wind travels west. Ephraim must have gone west from Assyria' (Armstrong 1967: 113). Op grond van gedeeltes daarby gelees soos Psalm 89: 26, Jeremia 3: 11-12, Hosea 11: 8, 10, Jesaja 49: 3, 6 en 41: 1, 8, word tot die gevolgtrekking geraak: 'So, finally, today, as in Jeremiah's day, the House of Israel is in the Isles, which are "in the sea", the Chief of the Nations, Northwest of Jerusalem, a coast-dwelling and therefore sea-dominant people' (Armstrong 1967: 115). Dit beteken dat Efraim Brittanje is en Manasse Amerika.

Die Suid-Afrikaanse weergawe van die teorie meen egter dat die trek van 2520 jaar uiteindelik in Suid-Afrika geeïndig het, wat die 'be- 
stemde plek' volgens 2 Samuel 7: 10 is (Opperman 1986: 25). Jesaja 18 en Sefanja 3 sê dat die verstrooide volk van die gebiede anderkant die riviere van Kus moet terugkeer na Palestina. 'Dit is die gedeelte tussen Kaapstad (die suidpunt van Afrika) en die riviere van Etiopië (Hayes sa: 23). Hierdie riviere het ' $n$ waterdrumpel gevorm wat die Kusiete, wat ten noorde daarvan gebly het, nie kon oorsteek nie. Die dele ten suide van die riviere is volgens Deuteronomium 32: 8 uitgehou vir die deel van die volk Israel wat hulle aan die suidpunt van Afrika sou kom vestig (Van der Gaag 1985: 4).

Dit het heilsimplikasies om hierdie gebied noukeurig vas te stel. Sefanja 3: 10-13 saam met Levitikus 26: 33, 1 Konings 14: 15, Esegiël 5: 10 en 6: 8 dui aan dat '. . . die volk moet in die suidpunt van Afrika wees, anders kan 'n hele klomp profesieë nie vervul word nie . . Sef 3 : 10 sê tog uitdruklik dat die verstrooide volk van die onderkant van die Zambezi as 'n volk sal terugkeer na Palestina' (Hayes sa: 24).

\section{ETNISITEIT EN HEIL}

Die gesigshoek van die eksponente van die Israelvisie is die dryfveer agter die verskillende leestegnieke wat aangewend word om te bewys dat die blankes Israel is. Hierdie gesigshoek neem beslis ideologiese omvang aan. Dit blyk daaruit dat die Blanke volgens hierdie siening vir die res van die wêreld tot groot voordeel is deur hulle wysheid en kennis. 'As hulle uitbaster, dan verdwyn hierdie vermoë en dien hulle nie meer die doel van God nie' (Eksteen 1980: 73). Read en Van der Kemp het deur hulle ondertrouing met gekleurdes 'geen benul wat ook al aangaande die kennis van God of sy wil getoon nie' (Opperman 1986: 17). Die volksvermenging wat die Roomse Kerk voorstaan '. . . is in God se oog 'n gruwel, net soos alles wat onrein is 'n gruwel is voor die Here' (Bybelstudiekring Plumstead 1987: 3). In al hierdie gevalle word behoud van blanke etnisiteit as die uitdruklike wil van God beskou.

Ook in God se wette is die blankheid verskans. Wanneer God sy wil vir Israel te kenne gee in die vorm van wette en verordeninge, word hierdie wetgewing deur die Israelvisie-voorstanders as ewig en onveranderlik gesien en letterlik afdwingbaar op diegene wat vandag as Israel bekend staan. Op eklektiese wyse word egter baie van hierdie verordeninge, soos byvoorbeeld die besnydenis, totaal buite rekening gelaat. Dit is eerder die talle afskeidings- en afsonderingsgebooie in die Bybel waarop die klem val. Uit hierdie tipe verordeninge is dit vir hulle 
duidelik: 'Die essensie van die Bybelboodskap is dus dat Israel hom moet afsonder en afskei van die volke' (Swart sa: 29). Josua 23: 7, 12, 13, Deuteronomium 26: 18, 19 en Numeri 22 en 23 bevat almal voorskrifte aan Israel om hom af te sonder van die nasies - wat vandag as rassediskriminasie beskryf sou word. 'Wegbeweeg van diskriminasie is dus niks anders as wegbeweeg van die verbond en wette van God self nie. Dis 'n oorsaak van Satanisme' (Eksteen 1980: 33). Uit Genesis 6: 1-4 word afgelei: '.. die onheilige vermenging was die sonde waarvoor die dood en die sondvloed die straf van God was' (Swart sa: 8). Daaruit is duidelik: "n Mens mag dus net trou met jou eie soort, met die kinders van jou volk, jy mag nie agter vreemde vlees aanloop nie' (Judas 7) (Swart sa: 8).

Ook in die kosmiese stryd tussen God en Satan speel die behoud van blanke etnisiteit volgens hierdie persepsie ' $n$ wesenlike rol. Uit Isak is gebore '. . .'n wonderras aan God geoffer as diensvolk en draers van die Evangelie' (Studiegroep Aktueel Windhoek sa: 4). Die satan het egter ‘. sy addersaad (Esau) saam met dié van die Godsaad (Jakob) in die baarmoeder van Rebekka (laat) beland, wat 'n worstelstryd in haar veroorsaak om eerste gebore te word. Die stryd tussen die twee sade sou voortduur tot die einde' (Studiegroep Aktueel Windhoek sa: 4). So het die satan probeer om die saad van die vrou te vermeng, want as hy dit kon infiltreer '... kon hy die geboorte van die eintlike Saad verhinder vanuit die suiwer Messiaanse bloedlyn' (Studiegroep Aktueel Windhoek-Esau sa: 5). Tot op hede kan in die politieke situasies van die dag en die internasionale intriges gesien word hoe die Satan die Tien Stamme probeer vernietig om so die wederkoms te verhoed. 'Die mikpunt is die vernietiging of vermenging van die ganse Westerse Beskawing' (Neser sa: 21). Met die behoud al dan nie van die blanke Westerse beskawing staan of val die geskiedenis van God se Koninkryk.

\section{DIE ROL VAN DIE ILLUMINATI}

Ook internasionaal-politiese aspekte speel 'n rol in die leesproses. In die kosmiese stryd moet Israel 'n verbete geveg aanknoop om sy blanke Israel identiteit te behou. Die groot mag waarmee hulle te doen het, is die sogenaamde Babiloniese stelsel van die satan. In Daniël word hierdie Babiloniese anti-God stelsel uitgebeeld. 'Dit is die orde of organisasie waarin Satan hierdie ongelowige wêreld en sy mense 
georganiseer het op die kosmiese beginsels van geweld, hebsug, selfsug, ambisie en plesier' (Neser [1979]: 22). Die Babiloniese stelsel is ook Mammon, die geldstelsel waardeur die wêreld beheer word. Die Goud Standaard is in Babel meer as 2520 jaar gelede reeds aangeneem, 'n stelsel waarvolgens ' $n$ klein uitgesoekte elite floreer ten koste van die massa, 'n stelsel wat Openbaring beskryf as die groot Babilon (Neser [1979]: 44). Hierdie stelsel is in die hande van 'n groep mense wat die geldmag in die wêreld beheer en bekend staan as die Illuminati. Die Illuminati is die geldmag onder leiding van die Rothchilds. Hulle propageer die leuen dat die Jode Israel is (Opperman 1986: 10). Die Jode vorm deur slinksheid die topstruktuur van die lluminati, dit wil sê die groot geldmag van die wêreld. Een van die arms waardeur hulle regeer, is die Vrymesselaars (Steenkamp sa: 7).

\section{DIE ALLEENSTRYD VAN DIE INGELIGTES}

Die groot waarheid van die Bybel vir die Israelvisie is die letterlike blanke identiteit van Israel. Dit is die 'goeie nuus, wat, behalwe dat dit die enigste evangelie in die Bybel is, dit ook die enigste evangelie is wat hoop en verlossing aan ons volk verkondig' (Hayes sa: 83). Die probleem is nou dat die predikante van die kerk nie hierdie identiteit van die wit volk ken nie en die leuen verkoop dat almal afkomstig is van die een stamvader Adam (Opperman 1986: 10). Daardeur staan hulle skuldig aan die aanklag van Esegiël 34: 4 dat die herders die goeie van die volk weerhou. Sodoende word die wit bondsvolk van sy identiteit en erfenis ontneem deur alles te verdraai:

Die volkseenheid word verbreek ... almal is nou welkom. Alle tipes in die Bybelteks word geskend, alle numerologiese waardes word verdraai en alle beloftes word nou vergeestelik. Die oorspronklike verbond word verwerp en 'n nuwe testament word opgetrek (Weich 1986: 2).

Die aanklag teen die kerk is dus viervoudig:

Eerstens weerhou sy predikers die waarheid van hulle werklike identiteit van die volk omdat hulle dit nie ken nie en eerder dienstig is aan '... daardie instansie wat haarself die kerk noem, nie om die waarheid te verkondig nie, maar haar leerstellings en dogmatiek' (Opperman 1986: 3). 
Tweedens fouteer die priesters en predikante deurdat hulle leer dat Israel nie meer in die vlees nie, maar slegs in die gees bestaan (Eksteen 1980: 73). Beide die Protestantisme en die Roomse Kerk huldig die dwaling van 'n geestelike Israel en 'n geestelike koninkryk (Studiegroep Aktueel Windhoek-Raadsplan sa: 9).

Derdens word die identiteit van die Godsvolk verv.reem deur die on-Bybelse stelling dat almal, ongeag kleur of ras, lid van die kerk kan word. Die sendingbevel is ook aangepas aan die idee van 'n geestelike Israel om die kerk saam te stel uit al die volke (Bybelstudiekring Plumstead 1987: 3).

Die vierde klag is dat die kerk sodoende 'n bondgenoot van die Satan geword het. Aan die uitwissing of verbastering van die Godsvolk deur die Satan '. . . werk feitlik alle Christelike Kerke (onbewustelik) saam' (Studiegroep Aktueel Windhoek-Esau sa: 28). Die gevestigde tradisionele kerke sien nie die kosmiese stryd tussen die fisiese nageslag van God en die van Satan raak nie, omdat dit verskil van mens tot mens, bevestig weens die verskil in hulle herkoms (Studiegroep Aktueel Windhoek-Raadsplan sa: 1). Die onderskeid tussen die huis van Juda en die huis van Israel, die Jode en die ware Israel, soos blyk uit Jeremia 3: 6-11, word doelbewus geïgnoreer. 'And yet opponents of the Truth revealed in this book deny these plain scripture - and attempt to "discredit us who reveal it' (Armstrong 1967: 94). Op dié manier is die kerk nie aan die kant van die waarheid nie, maar die medewerker van die satan om die volk van God te vernietig.

\section{EIE SKRIFONDERSOEK}

Omdat die kerk nie vir hulle 'n betroubare verklaarder van die Bybel is nie, is dit belangrik volgens die Israelvisie dat elke leser self die Skrif sal ondersoek. Daar is vir die 'wit volk van Yahweh' net een weg oop: '. . . dit is om hulle te leer om die Skrifte vir hulle self te bestudeer' (Opperman 1986: 3). Dit moet nie aan die kerk of die predikante oorgelaat word om te sê wat waar is nie.

Alhoewel hierdie voorneme baie goed klink, is dit duidelik dat die selflees van die Bybel geverg word omdat die uitgangspunt van die Israelvisie in die ander leesmodelle ontbreek. In 'n oproep soos die volgende, moet 'inlees' verstaan word as die tradisionele kerklike uitleg en 'raaksien' as die spesifieke standpunt van die Israelvisie: 
Laat ons die Bybel toelaat om homself te verklaar, dan sal ons nie in die plek beland waar ons sommige dinge in die Bybel inlees wat nie daar behoort te wees nie, en weer ander dinge raaksien wat duidelik daar staan nie (Neser [1979]: 42).

Die leesmodel wat hier geverg word, is een wat op die lees van die Israelvisie geskoei is. Vir Swart beteken die 'waarheid' wat in die Skrif gevind moet word, die fenomeen van etniese verskille. Sy studie openbaar aan hom

' $n$ waarheid wat op die Woord gebaseer is en tog rekening hou met die wetmatighede en lewenswerklikhede soos wat die wetenskap God se wonderbaarlike skepping vir ons ontsluit (Swart sa: ongenommer)

Uiterste versigtigheid moet volgens hom by die Skrifuitleg aan die dag gelê word, want betekenis kan verander deur klemverskuiwing, sodat Galasiërs 3: 7

volgens die nuwere humanistiese siening beteken dat iemand selfs oor die rassegrense ' $n$ kind van Abraham kan word - iets wat in terme van die wetenskap en die chromosometeorie geheel en al onmoontlik is - en dit is ongelukkig vandag die algemeen aanvaarde uitleg, alhoewel geheel-en-al onwetenskaplik (Swart sa: 41).

Die dominante posisie wat die standpunte van die Israelvisie in hierdie leesmodel inneem, is duidelik in die redenasies van Hayes. Hy meen dat die Bybel verkeerd verstaan word, omdat daar nie gekyk word met wie daar in die Bybel gepraat word nie. Met wie gepraat word, is tog ons van die hede, die blanke wat aangedui word as diegene anderkant die riviere van Kus (Hayes sa: 9). Dat dit ook nie vir die mense voor ons tyd bedoel was nie, blyk uit Jesaja 18.

Dit het skynbaar ook nooit op iemand betrekking gehad nie. Die feit dat die hoofstuk 'n bietjie verkeerd vertaal is was natuurlik ' $n$ bestiering van Bo. Dit was 'n uitstekende metode om sy profesieë aangaande ons geheim te hou tot reg aan die einde (Hayes sa: 32 ).

Die tipiese aanklag van skeurgroepe teen die huidige Bybelvertalings kom ook hier voor. Hulle standpunt is dat die vertalings '... are inaccurate in some crucial aspects' (Sire 1980: 34). Vanweë hulle 
gewaande dieper insig in die waarheid van die Bybel kan hulle dan ook kommentaar lewer op die korrektheid van die Bybelvertaling (veral waar ' $n$ alternatiewe vertaling die Israelvisie beter sou dien). Matteus 16: 18 se ekklésía moet nie met 'kerk' vertaal word nie, maar met 'volk' (Neser sa: 15). 'Jy moet jou naaste liefhê', lyk of dit beter verstaan kan word as 'Jy moet die wat soos jy is liefhê' (Swart sa: 42). Die aanpassing om 'n geestelike Israel te verstaan, is gemaak in die vertaling van Deuteronomium 23: 2 (Bybelstudiekring Plumstead 1987: 3). Levitikus 26: 18 moet vertaal word met 'seven prophetic times' (Armstrong 1967: 144).

\section{DESTRUKSIE OF DEKONSTRUKSIE?}

Ten spyte van alle pogings van die eksponente se kant om die Israelvisie met die Bybelteks te substansieer, kan nie van die leesprosesse, soos dit by die verskillende outeurs voorgekom het, gesê word dat dit werklik van tweerigting kommunikasie met die Bybelteks getuig nie. Van die gedagtewêreld en denke van die Bybelouteurs kom amper niks tereg in die finale leesproses nie. Die vraag na die Bybelouteurs se gesigspunt word doodeenvoudig net nooit gevra nie. Die gekodeerde teks kom wel aanhoudend voor in die lesers se resepsie, maar dit is slegs die woorde en formules met totaal nuwe inhoude. Hierdie nuwe inhoude het nie gegroei uit 'n werklike ontmoeting met die tekswêreld of die wêreld van die Bybelouteurs nie, maar kom uit 'n ideologiese lewensiening wat deurweek is van die Blanke Israelteorie.

Buiten die deurtastende teologiese kritiek wat op hierdie etniese ideologie gelewer kan word, moet uit die hoek van die dissipline van die hermeneutiek gesê word dat ons hier met uiters arbitrêre dekonstruksie te doen het. Ons moet hier eerder van destruksie van die Bybelteks, as van interaktiewe dekonstruksie, wat in gesonde kommunikatiewe teksresepsie voorkom, praat.

\section{Literatuurverwysings}

AKSIE AKTUEEL PERDEKOP sa. Die groot sendingopdrag?

ARMSTRONG, HW 1967. The United States and British Commonwealth in prophecy.

Pasadena: Ambassador College.

BYBELSTUDIEKRING PLUMSTEAD 1987. Skeuring wat nou? Plumstead.

CARSON, DA 1986. Exegetical fallacies. Grand Rapids: Baker.

DEIST, FE \& VORSTER, WS 1986. Woorde wat ver kom. Kaapstad: Tafelberg. 
EDWARDS, BL 1986. Deconstruction and rehabilitation: CS Lewis' defence of western textuality. JETS 29/2, 205-214.

EKSTEEN, MC 1980. Die worstelstryd teen die wêreldheersers en die owerhede. Vryheid: Vryheid.

HAYES, R sa. Suid-Afrika: Die land oorkant die riviere van Kus (Ethiopië) Plaston.

HOFMEYR, J sa. Hoor van Gods apartheid. Constantia.

NESER, FWC [1979]. Die boek van Daniell. Vereeniging: Prestige.

NESER, FWC sa. Die 'Verlore' tien stamme van Israel. Vereeniging: Prestige.

OPPERMAN, R 1986. Oorsprong van die wit volk van Suid-Afrika. Kaapstad: Jasher.

PELSER, F] sa. Waarom glo ons ons is Israel?

SIRE, JW 1980. Scripture twisting: 20 ways the cults misread the Bible. Illinois: Inter-Varsity Press.

STEENKAMP, GJ sa. Die wonder van die uitverkiesing. Kuruman.

STUDIEGROEP AKTUEEL WINDHOEK sa. Die raadsplan van God. Windhoek.

STUDIEGROEP AKTUEEL WINDHOEK sa. Esau (Edom-Amalek-Jood) versus Jakob (Israel)

Studie $\mathrm{nr}$ 2. Windhoek.

SWART, H sa. So spreek die Woord. Innesdale.

VAN AARDE, AG 1985. Skrifgebruik: Hermeneutiese riglyne. HTS 43, 325-351.

VAN DER GAAG, A 1985. Brief aan die verstrooide Israeliete in die suidpunt van Afrika: Die land oorkant die riviere van Kus. Alkantrand.

WEICH, SJF 1986. YAHWEH: Dwaalleer of openbaring? Kaapstad: Jasher.

WUELLNER, W 1987. Where is rhetorical criticism taking us? CBQ 49, 448-463. 